mechanical engineers will be hoping that this time their efforts to act as a reorganization corporation for the engineering industry come off. Others, scanning the list of engineering institutions, can easily see some candidates for mergers. The Institution of Railway Signal Engineers and the Institution of Locomotive Engineers look obvious bedfellows. And it is hard to see why the Institution of Mining Engineers, which looks after coal and iron ore mining, should be a separate body from the Institution of Mining and Metallurgy, which covers mining other than coal, and metallurgy other than iron. The most improbable institution of all is the Institution of Polish Engineers in Great Britain, established in 1940. Surprisingly, it still has 500 members.

\section{Long Short Story}

THe appointment at last of a new chairman to Short Brothers and Harland, the Belfast aircraft company, marks the end of an episode which has won few friends for the Ministry of Technology. Some two-thirds of the company is owned by the British Government, which therefore has an important say in its cperation. In June last year, readers of the Daily Express and the then chairman, Mr C. E. Wrangham, in that order, discovered that $\mathrm{Mr}$ Wrangham was to be asked to resign his job. It seems possible that the Minister, Mr Benn, had not even met Mr Wrangham.

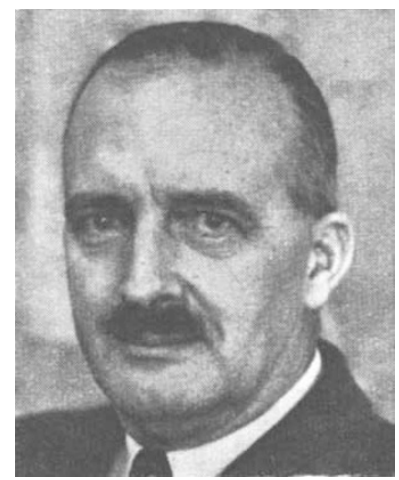

Air Vice-Marshal E. M. F. Grundy.

Mr Benn has not yet given the board of Short Brothers or the House of Commons a reason for his decision. In reply to six questions tabled on the matter on July 11, 1967, Mr Benn referred in the House of Commons to the substantial loss incurred by Shorts on the Belfast air freighter before Mr Wrangham's chairmanship, and the need for a reorganization to regain profitability. "This reorganization, which has already begun, can, I believe, best be carried through under the leadership of a new chairman." The ground for Mr Benn's belief, it has been suggested, was the Government's desire to see the company diversify itself out of the aircraft industry. Was it Mr Wrangham's fault that he was too successful in keeping Shorts in it? The company's troubles began in 1960 when it accepted a government order for ten Belfast aircraft in the belief that further orders would follow. None did, and the consequent loss of some $£ 15$ million made the company heavily dependent on government funds. Since that time Shorts has developed the Skyvan, a small two-engined freighter, and has built up a thriving export market for its Seacat guided missile. Substantial hopes are also placed on Blowpipe, a radar controlled guided weapon against low-flying aircraft which can be carried and operated by one man. In addition, the company has contracts for the wings of the Fokker 28 and 228 jet airliners, the engine pods for the RollsRoyce RB 203 engines and the wing tips of the Phantom. In 1967 the company won the Queen's Award to industry.

It may be a measure of disenchantment in British industry with the Ministry's handling of the matter that it has taken until now to find a new chairman for the company. He is Air Marshal Sir Edouard Grundy, who has been managing director of Royston Instruments since 1966. Royston Instruments, which manufactured the Midas flight recorder, was a member of the Royston Group of Companics, now in liquidation. Sir Edouard has had a distinguished career in the Royal Air Force and was Controller of Guided Weapons and Electronics in the Ministry of Aviation from 1962 to 1966 . His experience of the RAF, government and industry should stand him in good stead if he is to keep Shorts in business and retain Mr Benn's favour.

\section{Beyond the Classroom}

How can any institution in America now be in education and not in politics? The answer of the Dean of Harvard's Graduate School of Education is that it cannot. His report for the academic year of 1966-67 is a chilling document. The American faith in the public-that is, tax-supported and tuitionless-school is no longer justified. Urban schools are failing the "deprived" today, as suburban schools failed the "academically talented" fifteen years ago. And the Federal Government's entrance into educational reform-marked by an initial infusion of $\$ 1.2$ billion in 1966-has not justified the hopes held out for it. The critics - white and Negro-are right to be disillusioned.

Even the enthusiasm which greeted the entrance of large corporations such as IBM and Time Inc. into the business of selling textbooks and making teaching machines seems to have been misplaced, according to Dr Theodore Sizer, dean of the school. Dr Sizer maintains that many of these companies have been rudely shocked. The school market is scattered and requires a large sales force; local school boards have little money for experimentation and teachers prefer to buy what is familiar. And "the gadgetry of computers and teaching machines and the rest has yielded interesting, but financially intolerable, results". Malaise has hit the education profession itself. State commissioners of education seem ready to wrest control away from the Office of Education in Washington; the private philanthropic foundations and the National Science Foundation give hints of stopping their outpourings of money into educational reforms. And the teachers themselves, underpaid-their average salary in 1966-67 was $\$ 6,820$ - are not only having success at becoming trade unionists but are being truculent as well. The state of American education is uneasy indeed.

Dr Sizer could almost be accused of exaggerating the darkness to accentuate the light of his own school at Harvard. It has faced the challenge pretty squarely, by accepting as a fact the proposition that much of 
education, and perhaps the best of it, takes place outside the classroom. The candidate for the doctorate in education can no longer expect to be trained to be a polished performer behind the desk; he must learn to be something of the street-corner social worker.

This change of direction emerged from a project called the Center for Research and Development on Educational Differences. Sustained by federal research money, various inquiries "of a scientific nature" were made into what influences determine a child's capacity to learn from formal education. One study looked into the mental abilities of six-year-olds and into the contrasting patterns possessed by children from different social classes and ethnic groups around Boston. In another project, researchers worked with Negro boys from ten to fourteen years old in one of Boston's most solidly black slums. For slightly older students, courses were offered in a variety of settings for real or potential school drop-outs, and were successful in making the boys more interested in academic achievement. The result of these and a number of other experiments was the abandonment by Harvard's Graduate School of Education of the traditional idea of its purpose--the study and improvement of instruction in the classroom-for the radical belief that education's educators must be expressly concerned with what children do and can learn outside school.

Although the interests of the school range widelyfrom improving the design of Boston's school buildings to improving the teaching of physics, from Boston to Minnesota and Nigeria-its primary concern has been what it offers to the postgraduate students who come to Cambridge, Massachusetts, to take higher degrees in education. The new philosophy affects them directly. One of their programmes, instead of concentrating on teaching academic subjects in classrooms, has turned training teachers into tutors, asking them to spend time with children as individuals and to follow no set curriculum. Another, the training of primary school teachers, has asked them to study a few subjects well, rather than the usual small helping of everything; this, it is hoped, will encourage more men to become teachers of the younger age group.

These steps toward revolution will be intensified in the present academic year (although the Educational Differences Center has had to be reorganized because of educational differences with the Federal Office of Education). But the aim in the future will be the same as Dean Sizer described it for the year just concluded: "to prevent the national spirit of malaise from turning in our particular community to one of negative cynicism. Schools are failing, yes; but this does not mean that they will or should always fail".

\section{Student Participation}

THE bold recommendations that students at the Lcndon School of Economics should be granted membership of its three main governing bodies create a situation unparalleled in any university or institution in Britain or, indeed, in the world. These recommendations appear in the first report on the machinery of government of the school, signed by eighteen members of a committee chaired by Lord Bridges.

The need for changes in the way in which LSE is governed has become increasingly obvious over the past few years, as a result of the growth of the school and the complexity of its activities. This need was first seen in August 1966 when Sir Sydney Caine presented specific proposals in a paper circulated to the Court of Governors and to the academic bodies in the school. On February 2, 1967, the Court of Governors agreed to establish a joint committee consisting of members of court and the academic body, and five student members were added to this committee.

The main object of student participation, the report says, is to secure student co-operation, thereby strengthening the unity of the school. It may also help to make accurate information on the school's activities available to all students. There are two ways in which students' participation could be achieved: by "consultation" which would need to be official, involving the establishment of joint student-staff consultative committees which would meet regularly to consider in advance matters on the agenda; the alternative scheme would involve the election or nomination of appropriately qualified students to serve as members of committees or other bodies. Of these two, the committee decided that "membership" would be most advantageous.

Many of the recommendations follow the general proposals of Sir Sydney Caine's memorandum. The report recommends that there should be about sixty members of court, including twelve members of academic staff and four to eight student members. A council should be established to replace the existing Standing Committee as the central budgetary authority of the school, and it is proposed that three members of the council should be students. The committee recommends that a senate be established to have executive powers in academic matters, and that it should include five student members. Students will not be allowed, however, to become members of the Academic Boardthe forum through which all teachers would discuss and be asked to endorse important issues of policy. In addition, students would be members of some fourteen sub-committees of the senate and council, but staff appointments and promotions would be made by committees other than those on which students are members.

A minority report presented by two student members, Mr Dick Atkinson and Mr David Adelstein, lists a number of criticisms of the majority report. In the introductory comment, it is suggested that this report has limited itself to "managerially specified problems" and ignored "contemporary educational matters". In addition to challenging the assumptions and limitations of the report, $\mathrm{Mr}$ Atkinson and $\mathrm{Mr}$ Adelstein suggest a number of alternative proposals. For example, they consider that the court should comprise forty representatives of "society", including persons in trade unions, the theatre, the professions, peers of the realm and others. Furthermore, they suggest that the court should be assisted in its functions by electing a committee consisting of three governors, three staff and three students, all of whom should be members of court.

\section{Academic Awards}

Contrinuing success is reported by the Council for National Academic Awards (CNAA) in its third annual report covering the period up to September 1967. Initial misgivings about the success of the council are 